\title{
PENGUJIAN BAHAN BAKAR BIOFUEL HASIL PIROLISIS BOTOL PLASTIK PADA SEPEDA MOTOR
}

\author{
Purnomo Nurdianto, Ika Kusuma Nugraheni, Reza Taufiqi Ivana \\ Jurusan Mesin Otomotif Politeknik Negeri Tanah Laut \\ Email : Ipuranaesinten@gmail.com
}

\begin{abstract}
ABSTRAK
Kelangkaan bahan bakar merupakan masalah Negara Indonesia, minyak bumi masih menjadi penggerak utama perekonomian dunia, minyak bumi merupakan sumber daya energi yang tidak dapat diperbaharui. Disatu sisi sejak pertama kali ditemukan pada tahun 1907, kebutuhan plastik terus meningkat hingga mengalami kenaikan rata-rata 200 ton per tahun, Plastik yang sudah menjadi sampah berdampak negatif terhadap lingkungan maupun kesehatan manusia, karena tidak dapat terurai dengan cepat dan dapat menurunkan kesuburan tanah. Salah satu alternatif penanganan sampah plastik adalah dengan mengkonversi sampah plastik menjadi bahan bakar minyak dengan metode pirolisis, pirolisis adalah proses dekomposisi suatu bahan pada suhu tinggi tanpa adanya udara atau dengan udara terbatas, yang dihasilkan dari proses pirolisis adalah arang (char), minyak, dan gas. Cairan dari hasil pirolisis inilah yang akan digunakan sebagai campuran bahan bakar, setelah diketahui kandungan dari bahan bakar hasil pirolisis kemudian diuji coba menggunakan mesin sepeda motor empat tak satu silinder merek Honda Beat 108 cc. Untuk mengetahui kandungan emisi gas buang dengan variasi bahan bakar premium murni, dan campuran bahan bakar dengan variasi perbandingan 95\% premium berbanding 5\% biofuel, dan $80 \%$ premium berbanding 20\% biofuel, setelah di uji coba hasil percampuran bahan bakar premium dan biofuel ini masih layak digunakan karena masih di bawah nilai ambang batas berdasarkan Keputusan Menteri Lingkungan Hidup Nomor 05 Tahun 2006.
\end{abstract}

Kata kunci: Kelangkaan bahan bakar, sampah plastik, pirolisis.

\begin{abstract}
Fuel shortage is a problem the State of Indonesia, petroleum is still the main driver of the world economy, petroleum is an energy resource that is not renewable. On one side since it was first discovered in 1907, plastic necessities continue to rise to rise an average of 200 tons per year, plastic Excellence Plastic them strong, lightweight, flexible, rust resistant, not easily broken, easily be colored, malleable, and heat insulation and electricity. Plastic trash that has become negative impact on the environment and human health, because it can not decompose quickly and can reduce soil fertility. One alternative handling of plastic waste is to convert plastic waste into fuel oil by the method of pyrolysis, pyrolysis is a process of decomposition of a material at high temperatures in the absence of air or with limited ventilation, resulting from the pyrolysis process is char (char), oil, and gas. Fluid from the pyrolysis results that will be used as a fuel mixture, having known the content of the fuel pyrolysis results then tested using a motorcycle engine four-stroke single-cylinder 108 cc brands Honda Beat. to determine the content of exhaust emissions with a variety of premium fuel is pure, and the fuel mixture ratio variation of $95 \%$ premium versus $5 \%$ biofuel and $80 \%$ premium versus $20 \%$ biofuel, after the test result of a mixture of premium fuel and biofuel is still fit for use because it is still below the threshold value based on the Ministry of Environment No. 05 of 2006.
\end{abstract} Keywords-scarcity of fuel, plastic waste, pyrolysis.

\section{PENDAHULUAN}

Kelangkaan bahan bakar merupakan masalah yang sering terjadi di Negara Indonesia. Minyak bumi merupakan sumber daya energi yang tidak dapat diperbaharui. Hal tersebut dibuktikan bahwa cadangan minyak dan gas bumi di Indonesia diperkirakan tidak akan berumur lebih dari 25 tahun, sehingga apabila tidak ditemukan cadangan baru maka hanya akan cukup untuk memenuhi konsumsi 18 tahun saja untuk minyak bumi, sekitar 50 tahun untuk gas bumi dan sekitar 150 tahun untuk batu bara (Tim Nasional Pengembangan BBN, 2007:35). Saat ini kebutuhan bahan bakar semakin meningkat tetapi sumber bahan bakar fosil semakin menipis, maka perlu adanya suatu energi terbarukan guna mengatasi kelangkaan bahan bakar fosil.

Sejak pertama kali ditemukan pada tahun 1907, penggunaan plastik dan barang-barang berbahan dasar plastik semakin meningkat. Peningkatan penggunaan plastik ini merupakan konsekuensi dari berkembangnya teknologi, industri dan juga jumlah populasi penduduk Indonesia, Akibat dari penggunaan plastik ini adalah meningkatnya jumlah sampah plastik yang dihasilkan, berdasarkan asumsi Kementrian Lingkungan Hidup (KLH), setiap hari warga indonesia menghasilkan sampah 
sebanyak 0,8 kilogram sampah per orang atau secara total sebanyak $189 \mathrm{ribu}$ ton sampah/hari."Hendrawati (2016) mengemukakan bahwa pada tahun 2016 Indonesia menjadi negara penghasil sampah plastik terbesar ke 2 di dunia dengan jumlah sampah plastik sebanyak 187,2 juta ton, setelah Cina dengan jumlah sampah plastik sebanyak 262,9 juta ton". Di daerah Tanah Laut saja rata-rata jumlah sampah yang masuk ke TPA Bakunci sebanyak 85 Ton perhari (Dinas Pekerjaan Umum Kabupaten Tanah Laut, 2016). Untuk menangani masalah sampah adalah dengan mendaur ulang sampah plastik menjadi barang yang lebih berguna, salah satu alternatif penanganan sampah plastik yang saat ini banyak diteliti dan dikembangkan adalah dengan mengkonversi sampah plastik menjadi bahan bakar minyak dengan metode pirolisis, dengan cara ini dua permasalahan penting bisa diatasi, yaitu bahaya penumpukan sampah plastik dan diperoleh kembali bahan bakar minyak yang merupakan salah satu bahan baku plastik.

Pirolisis adalah proses dekomposisi suatu bahan pada suhu tinggi tanpa adanya udara atau dengan udara terbatas. Proses dekomposisi pada pirolisis ini juga sering disebut dengan devolatilisasi. Produk utama dari pirolisis yang dapat dihasilkan adalah arang (char), minyak, dan gas. Arang yang terbentuk dapat digunakan sebagai karbon aktif, sedangkan minyak yang dihasilkan dapat digunakan sebagai zat additif atau campuran dalam bahan bakar, sedangkan gas yang terbentuk dapat dibakar secara langsung (A.S Chaurasia., B.V Babu., 2005). Cairan dari hasil pirolisis inilah yang akan di gunakan sebagai campuran bahan bakar. dengan metode ini di harapkan dapat mengurangi masalah sampah pada lingkungan dan juga dapat mengurangi kebutuhan bahan bakar fosil, selain dapat mengurangi masalah sampah pemanfaatan limbah botol ini juga diharapkan dapat memenuhi kebutuhan bahan bakar di masa depan.

\section{Pembuatan Reaktor}

\section{METODOLOGI}

Dilakukan perakitan seperti gambar dibawah ini :

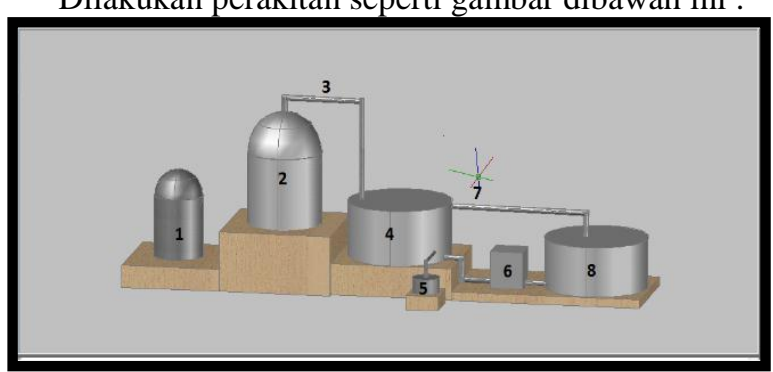

Gambar 1 Rancangan Reaktor Pirolisis

Keterangan:

1. Tabung gas

2. Reaktor pirolisis

3. Pipa minyak pirolisis

4. Unit pendingin

5. Tempat penampungan minyak pirolisis

6. Pompa air

7. Pipa pendingin

8. Bak penampungan air

\section{Persiapan Bahan Limbah Plastik}

Pertama - tamabotol plastik di bersihkan dari segala jenis kotoran dengan cara dicuci dengan air, kemudian di cacah dan dijemur dibawah sinar matahari hingga kering.

\section{Proses Pirolisis}

a. Bahan baku botol plastik sebanyak $1 \mathrm{~kg}$ dimasukkan kedalam reaktor.

b. Memasang pipa sambungan anatara lubang pengeluaran gas pirolisis dengan unit pendingin dan sambungan antara unit pendingin dengan tempat minyak pirolisis.

c. Dilakukan pemanasan pada suhu lebih kurang $200^{\circ} \mathrm{C}$ sampai semua sampah terdegredasi dengan sempurna.

d. Dihasilkan gas dan air yang bercampur dengan minyak.

\section{Karakteristik Minyak Hasil Pirolisis}

Metode analisa data yang digunakan meliputi viskositas, densitas dan flash point. Adapun cara dari pengujiannya adalah sebagai berikut:

\section{Viskositas}

Pada viscometer Ostwald yang diukur adalah waktu yang dibutuhkan oleh sejumlah cairan tertentu untuk mengalir melalui pipa kapiler dengan gaya yang disebabkan oleh berat cairan itu sendiri. Sejumlah cairan dipipet kedalam viscometer. Cairan kemudian dihisap melalui labu pengukur dari viscometer sampai permukaan cairan lebih tinggi dari batas a, cairan kemudian dibiarkan turun ketika permukaan cairan turun melewati batas a, stopwatch mulai dinyalakan dan ketika cairan melewati tanda batas b, stopwatch dimatikan. Jadi waktu yang dibutuhkan cairan untuk melalui jarak antara a dan $b$ dapat ditentukan.

2. Densitas

Timbang gelas bersekala kosong, kemudian masukkan cairan kedalam gelas tersebut, timbang gelas bersekala yang sudah berisi cairan, kemudian berat dari cairan di bagi volume, maka didapatlah massa jenis dari cairan tersebut.

3. Flash Point

Sampel dimasukkan ke dalam cawan, kemudian letakkan cawan pada alat dan pasang tutupnya. Stirrer dihubungkan dengan motor pengaduk, dan thermometer dipasang dengan baik. Setelah alat-alat dipasang dengan baik maka pasang stop kontak. Nyala api pemandu (pilot flame) dinyalakan dari aliran bahan bakar elpiji sdengan panjang nyala \pm 4 mm dan disiapkan di mulut penutup celah (shutter). Pemanas dinyalakan hingga suhu bahan bakar naik tidak lebih dari $5^{\circ} \mathrm{C}$ per menit (prediksi dahulu karakteristik bahan bakar). Alat penutup celah (shutter) dioperasikan sehingga api pemandu turun/masuk ke dalam cawan/cup dan biarkan \pm 2 detik, setelah itu kembalikan shutter pada posisi semula. Ulangi prosedur diatas untuk setiap kenaikan $4^{\circ} \mathrm{C} /$ menit hingga titik nyala / flash point dan titik bakar / fire point tercapai. Apabila ketika api 
pemandu masuk kedalam cairan uap bahan bakar tersulut dengan cepat maka suhu yang terbaca pada thermometer adalah flash point bahan bakar uji. Apabila saat api pemandu masuk kedalam cairan uap bahan bakar terbakar secara berlanjut maka suhu yang terbaca pada thermometer adalah fire point bahan bakar uji. Pengujian dilakukan 3 kali.

\section{Aplikasi Dan Pengujian Emisi Gas Buang}

Pengaplikasian minyak hasil pirolisis pada sepeda motor dengan perbandingan campuran bahan bakar $80 \%$ : $20 \%$, dimana $80 \%$ merupakan bahan bakar murni dan $20 \%$ bahan bakar minyak hasil pirolisis, campuran bahan bakar 95\% premium dan 5\% Biofuel, dan bahan bakar premium murni.Setelah bahan bakar dicampurkan dengan minyak hasil pirolisis maka selanjutnya masukan minyak tadi kedalam wadah yang sudah di modifikasi, Kemudian hidupkan sepeda motor.

Pengujian emisi gas buang dengan kondisi Idle menggunakan 3 variasi bahan bakar sebagai perbandingan, diantaranya bahan bakar premium murni dan bahan bakar campuran dengan komposisi campuran bahan bakar 95\% premium dan 5\% Biofuel, dan bahan bakar premium $80 \%$ dan Biofuel 20\%. Adapun alat yang digunakan pada pengujian ini adalah Automotive Gas Analizer.

\section{HASIL DAN PEMBAHASAN}

\section{Pembuatan Biofuel Botol Plastik}

Dari pengerjaan dan penyusunan tugas akhir dengan judul "PEMANFAATAN LIMBAH BOTOL PLASTIK MENJADI BAHAN BAKAR BIOFUEL DENGAN PROSES PIROLISIS" maka tugas akhir ini mendapatkan hasil sebagai berikut :

Pirolisis ini dilakukan dengan menggunakan tabung reaktor berkapasitas $1 \mathrm{~kg}$ dengan menggunakan bahan bakar gas sebagai media pembakar, dalam percobaan yang telah dilakukan sebanyak 3 kali percobaan jumlah minyak yang terbentuk ( $250 \mathrm{ml}$ ) pada suhu tertinggi reaktor $\left(183,3^{\circ} \mathrm{C}\right)$,

Dalam percobaan yang telah dilakukan sebanyak $3 \mathrm{kali}$ percobaan jumlah minyak yang terbentuk disajikan dalam Tabel 3 sebagai berikut:

Tabel 3 Hasil Pirolisis Botol Plastik

\begin{tabular}{|c|c|c|}
\hline $\begin{array}{c}\text { Percobaan } \\
\text { Ke - }\end{array}$ & $\begin{array}{c}\text { Bahan baku } \\
\text { plastik }(\mathrm{Kg})\end{array}$ & $\begin{array}{l}\text { Minyak yang } \\
\text { dihasilkan }(\mathrm{ml})\end{array}$ \\
\hline 1 & 1 & 250 \\
\hline 2 & 1 & 270 \\
\hline 3 & 1 & 230 \\
\hline Rata-rata & 1 & 250 \\
\hline
\end{tabular}

Jadi dari 3 kali percobaan tersebut di dapat jumlah total minyak sebanyak $250 \mathrm{ml}$ dalam setiap kali percobaan menggunakan bahan baku botol plastik PET.

Bahan bakar minyak hasil pirolisis ini tidak langsung digunakan sebagai bahan bakar kendaraan bermotor karena belum diketahui spesifikasi kandungan minyak hasil pirolisis tersebut apakah mendekati bensin atau bahan bakar solar, untuk itu dilakukanlah pengujian bahan yang meliputi Densitas, Viskositas, dan titik nyala. Setelah dilakukan pengujian di labolatorium didapatkan hasil pada Tabel 1 berikut:

Tabel 1 Karakteristik Biofuel yang dihasilkan

\begin{tabular}{|c|c|c|c|c|}
\hline No & $\begin{array}{c}\text { Parameter } \\
\text { Uji }\end{array}$ & Satuan & $\begin{array}{c}\text { Hasil } \\
\text { Uji }\end{array}$ & Metode Uji \\
\hline 1 & Densitas & $\mathrm{g} / \mathrm{cm}^{3}$ & 0,78 & Hydrometer \\
\hline 2 & Viskositas & $\mathrm{Cp}$ & 1,50 & Viscometer \\
\hline 3 & $\begin{array}{c}\text { Titik } \\
\text { Nyala }\end{array}$ & ${ }^{\circ} \mathrm{C}$ & 46,50 & Pembakaran \\
\hline
\end{tabular}

Setelah diketahui kandungan minyak pirolisis kemudian dibandingkan dengan Sifat bahan bakar yang dapat diketahui melalui Tabel 2 ini:

Tabel 2 Perbandingan Bahan bakar Pirolisis, Bensin, dan Solar.

\begin{tabular}{|c|c|c|c|c|}
\hline $\begin{array}{l}\mathrm{N} \\
\mathrm{O}\end{array}$ & $\begin{array}{l}\text { Parameter } \\
\text { Pembanding }\end{array}$ & $\begin{array}{c}\text { Bahan } \\
\text { bakar } \\
\text { pirolisis }\end{array}$ & Bensin & Solar \\
\hline 1 & Densitas & $0,78 \mathrm{~kg} / 1$ & $\begin{array}{c}0,71 \\
\text { sampai } \\
0,77 \\
\mathrm{~kg} / \mathrm{l} \\
\end{array}$ & $\begin{array}{c}0,815 \\
\text { sampai } \\
0,870 \\
\mathrm{~kg} / \mathrm{l} \\
\end{array}$ \\
\hline 2 & Viskositas & $1,50 \mathrm{Cp}$ & - & $\begin{array}{c}2,0 \\
\text { sampai } \\
5,0 \\
\mathrm{~mm}^{2} / \mathrm{s}\end{array}$ \\
\hline 3 & Titik Nyala & $46,50^{\circ} \mathrm{C}$ & $\begin{array}{l}\left(-10^{\circ}\right) \\
\text { sampai } \\
\left(-15^{\circ} \mathrm{C}\right)\end{array}$ & $\begin{array}{c}40 \\
\text { sampai } \\
100^{\circ} \mathrm{C} \\
\end{array}$ \\
\hline
\end{tabular}

Pengamatan minyak pirolisis secara fisual :

- Mudah terbakar

- Mudah menguap

Dari tabel diatas dapat diketahui bahwa densitas yang dimiliki bahan bakar pirolisis adalah $0,78 \mathrm{~kg} / \mathrm{l}$, dan bahan bakar bensin $0,71-0,77 \mathrm{~kg} / \mathrm{l}$, sedangkan solar 0,815 - 0,870 kg/l. Dari data tersebut dapat diketahui bahwa densitas yang dimilik minyak hasil pirolisis mendekati densitas yang dimiliki bensin.

Tabel diatas juga menunjukkan kandungan viskositas yang dimiliki bahan bakar pirolisis yaitu 1,50 Cp, viskositas bensin tidak diketahui, dan viskositas solar adalah $2,0-2,5 \mathrm{~mm}^{2} / \mathrm{s}$, pada data diatas terdapat perbedaan pada satuan kandungan viskositas antara bahan bakar pirolisis dan bahan bakar solar, hal tersebut dikarenakan perbedaan alat ukur yang digunakan pada saat pengujian kandungan bahan bakar.

Selain densitas dan viskositas tabel diatas juga menunjukkan titik nyala bahan bakar pirolisis, bensin, dan solar. Titik nyala yang dimiliki bahan bakar pirolisis adalah $46,50{ }^{\circ} \mathrm{C}$, bensin -10 sampai $-15^{\circ} \mathrm{C}$, dan solar $40-100^{\circ} \mathrm{C}$. Dari data tersebut dapat diketahui bahwa titik nyala yang dimiliki bahan bakar pirolisis mendekati solar, tetapi saat 
di amati secara fisual bahan bakar pirolisis memiliki sifat mudah terbakar dan mudah menguap, sehingga dimungkinkan bahwa bahan bakar pirolisis lebih mendekati karakteristik bensin.

Pada saat uji coba bahan bakar biofuel dicampur dengan bahan bakar premium, dengan variasi perbandingan $95 \%$ premium berbanding $5 \%$ biofuel, dan $80 \%$ premium berbanding $20 \%$ biofuel, pengujian dengan percampuran bahan bakar premium dan minyak hasil pirolisis yang dilakukan maksimal 20\%, karena pada penelitian terdahulu disarankan bahwa percampuran antara bahan bakar premium dan bahan bakar pirolisis yang melebihi $20 \%$ dapat menyebabkan nilai oktan dan viskositas berkurang.

\section{Hasil Uji Emisi}

Pengujian emisi dilakukan menggunakan mesin sepeda motor empat tak satu silinder merek Honda Beat $108 \mathrm{cc}$. Parameter yang diteliti adalah data emisi gas buang dengan bahan bakar premium murni, dan campuran bahan bakar dengan variasi perbandingan $95 \%$ premium berbanding $5 \%$ biofuel, dan $80 \%$ premium berbanding $20 \%$ biofuel.

Tabel 4 Hasil Pengujian Kandungan Emisi CO dalam \% Volume

\begin{tabular}{|c|c|c|c|}
\hline \multirow[b]{2}{*}{ RPM } & \multicolumn{3}{|c|}{$\begin{array}{l}\text { Hasil Pengujian Emisi CO dalam \% } \\
\text { Volume }\end{array}$} \\
\hline & Premium & $\begin{array}{c}\text { Premium95 } \\
\%+\text { Biofuel } \\
5 \%\end{array}$ & $\begin{array}{c}\text { Premium } 80 \% \\
+ \text { Biofuel } \\
20 \%\end{array}$ \\
\hline Idle & $0,12 \%$ & $0,11 \%$ & $0,9 \%$ \\
\hline
\end{tabular}

Berdasarkan Tabel 4, maka data angka tersebut dapat digambarkan melalui grafik sebagai berikut:

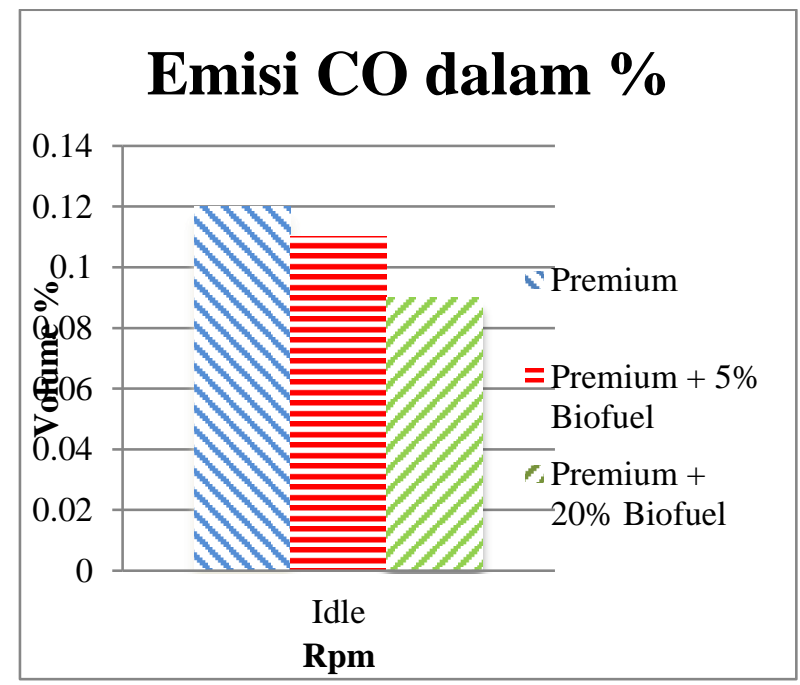

Gambar 2 Grafik Emisi CO

Pada bahan bakar premium murni kandungan $\mathrm{CO}$ yang dihasilkan sebesar $0,12 \%$, kemudian pada campuran premium + biofuel $5 \%$ kandungan $\mathrm{CO}$ yang dihasilkan masih berada di angka $0,11 \%$, setelah campuran premium + biofuel 20\% kandungan CO menurun menjadi 0,09\% Dari grafik diatas dapat diketahui bahwa kandungan $\mathrm{CO}$ yang dihasilkan dari campuran antara bahan bakar premium + biofuel semakin menurun. Hal ini dimungkinkan karena densitas biofuel yang lebih rendah dibandingkan premium, semakin tinggi berat jenis suatu zat semakin tinggi pula titik didih dan semakin sulit menjadi uap akibatnya bahan bakarsemakin sulit bereaksi dengan oksigen, sehingga memerlukan suhu lingkungan yang tinggi untuk terjadi campuran gas dengan oksigen.

Jumlah gas CO yang dikeluarkan oleh mesin kendaraan dipengaruhi oleh perbandingan antara udara dan bahan bakar yang dihisap oleh mesin ke dalam ruang bakar. Pada saat campuran kaya (kekurangan udara) emisi gas buang $\mathrm{CO}$ cenderung naik. Hal ini dikarenakan atom karbon (CO) yang berasal dari bahan bakar kekurangan oksigen $\left(\mathrm{O}_{2}\right)$ yang berasal dari udara untuk berikatan melalui reaksi kimia di dalam ruang bakar dan berubah menjadi karbon dioksida $\left(\mathrm{CO}_{2}\right)$. Sedangkan pada kondisi campuran miskin (kelebihan udara) konsentrasi $\mathrm{CO}$ berbanding lurus dengan campuran bahan bakar dan udara yang dihisap sehingga konsentrasi CO akan turun, karena oksigen yang berasal dari udara cukup untuk memenuhi reaksi dengan karbon membentuk $\mathrm{CO}_{2}$ (Warju, 2009).

Tabel 5 Hasil Pengujian Emisi HC dalam ppm Vol

\begin{tabular}{|c|c|c|c|}
\hline \multirow{2}{*}{ RPM } & \multicolumn{3}{|c|}{ Hasil Pengujian Emisi HC ppm Volume } \\
\cline { 2 - 4 } & Premium & $\begin{array}{c}\text { Premium + } \\
\text { Biofuel 5\% }\end{array}$ & $\begin{array}{c}\text { Premium }+ \\
\text { Biofuel 20\% }\end{array}$ \\
\hline Idle & 165 & 510 & 369 \\
\hline
\end{tabular}

Berdasarkan Tabel 5, maka data angka tersebut dapat digambarkan melalui grafik sebagai berikut:

\section{Emisi HC dalam ppm}

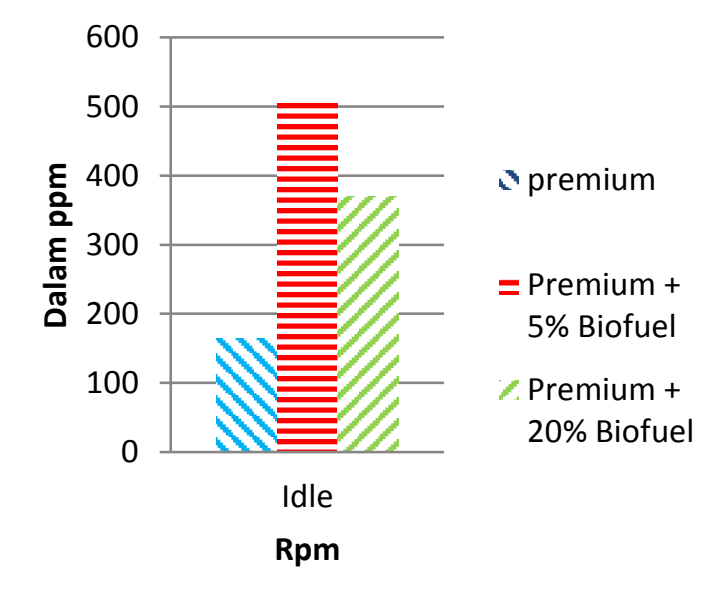

Gambar 3 Grafik Emisi HC

Dari data dan grafik diatas dapat diketahui bahwa kandungan $\mathrm{HC}$ pada campuran premium + Biofuel $5 \%$ mengalami kenaikan HC yang sangat tinggi yaitu 
mencapai 510 ppm, berbeda dengan campuran biofuel $20 \%$ yang mengalami kenaikan tidak terlalu tinggi, hal ini dimungkinkan karena bahan bakar biofuel memiki titik nyala yang tinggi yaitu sebesar $46,50^{\circ} \mathrm{C}$ sedangkan putaran mesin yang dihasilkan tidak terlalu tinggi, sehingga percikan bunga api yang dihasilakan juga melambat, hal ini menyebabkan bahan bakar tidak dapat terbakar sempurna sehingga kandungan $\mathrm{HC}$ menjadi meningkat.

Apabila campuran kurus (kurang bahan bakar), maka kosentrasi HC menjadi naik, hal ini disebabkan kurangnya pasokan bahan bakar sehingga menyebabkan rambatan bunga api menjadi lambat, bahan bakar akan segera keluar sebelum terbakar dengan sempurna. Pada kondisi campuran kaya (kurang udara), konsentrasi HC akan naik akibat dari adanya bahan bakar yang belum bereaksi dengan udara yang dikarenakan pasokan udara tidak cukup untuk bereaksi menjadi sempurna, sehingga ada sebagian hidrokarbon yang keluar pada saat proses pembuangan.

Tabel 6 Hasil Pengujian Kandungan Emisi $\mathrm{CO}_{2}$ dalam \% Volume

\begin{tabular}{|c|c|c|c|}
\hline \multirow{2}{*}{ RPM } & \multicolumn{3}{|c|}{ Hasil Pengujian Emisi $\mathrm{CO}_{2}$ dalam \% } \\
\cline { 2 - 4 } & Polume \\
\hline Idle & 4,3 & $\begin{array}{c}\text { Premium + } \\
\text { Biofuel 5\% }\end{array}$ & $\begin{array}{c}\text { Premium + } \\
\text { Biofuel 20\% }\end{array}$ \\
\hline
\end{tabular}

Berdasarkan tabel di atas, maka data angka tersebut dapat digambarkan melalui grafik sebagai berikut:

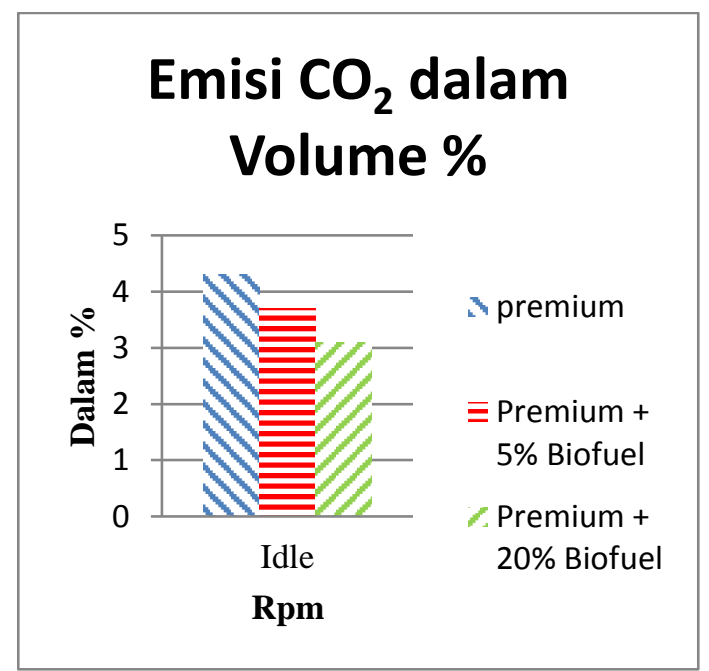

Gambar 4 Grafik Emisi CO2 Dalam Volume \%

Rendahnya kadar $\mathrm{CO}_{2}$ pada campuran bahan bakar + biofuel $5 \%$ dan $20 \%$ dimungkinkan karena titik nyala biofuel yang tinggi yaitu $46,50^{\circ} \mathrm{C}$ sedangkan titik nyala bensin -10 sampai $-15^{\circ} \mathrm{C}$ dan pada putaran rendah sudut pengapian cenderung mundur, sehingga berakibat pembakaran terlambat. Unsur yang terkandung dalam bahan bakar akan terbakar melalui pembakaran yang dihasilkan oleh bunga api atau busi. Pembakaran yang terlambat menyebabkan unsur $\mathrm{C}$ dan $\mathrm{O}$ tidak berubah menjadi $\mathrm{CO}_{2}$.

Tabel 7 Hasil Pengujian Kandungan Emisi $\mathrm{CO}_{2}$ dalam \% Vol

\begin{tabular}{|c|c|c|c|}
\hline \multirow{2}{*}{ RPM } & \multicolumn{3}{|c|}{ Hasil Pengujian Emisi $\mathrm{CO}_{2}$ dalam \% } \\
\cline { 2 - 4 } & Premium & $\begin{array}{c}\text { Premium + } \\
\text { Biofuel 5\% }\end{array}$ & $\begin{array}{c}\text { Premium + } \\
\text { Biofuel 20\% }\end{array}$ \\
\hline Idle & 4,3 & 3,7 & 3,1 \\
\hline
\end{tabular}

Berdasarkan Tabel di atas, maka data angka tersebut dapat digambarkan melalui grafik sebagai berikut:

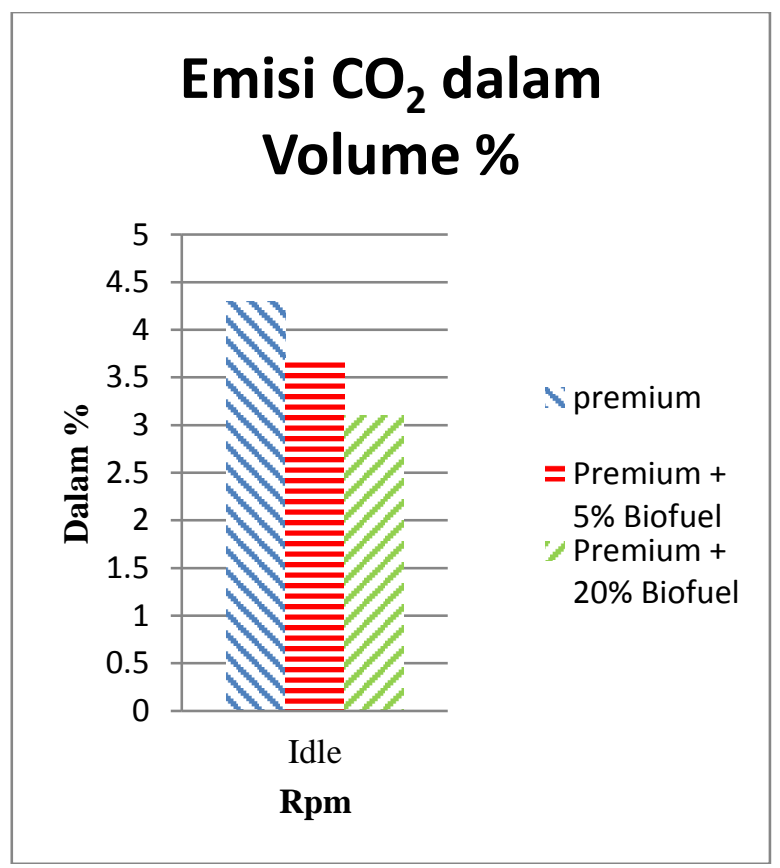

Gambar 5 Grafik Emisi $\mathrm{CO}_{2}$ Dalam \% Volume

Rendahnya kadar $\mathrm{CO}_{2}$ pada campuran bahan bakar + biofuel 5\% dan $20 \%$ dimungkinkan karena titik nyala biofuel yang tinggi yaitu $46,50^{\circ} \mathrm{C}$ sedangkan titik nyala bensin -10 sampai $-15{ }^{\circ} \mathrm{C}$ dan pada putaran rendah sudut pengapian cenderung mundur, sehingga berakibat pembakaran terlambat. Unsur yang terkandung dalam bahan bakar akan terbakar melalui pembakaran yang dihasilkan oleh bunga api atau busi. Pembakaran yang terlambat menyebabkan unsur $\mathrm{C}$ dan $\mathrm{O}$ tidak berubah menjadi $\mathrm{CO}_{2}$.

Tabel 8 Hasil Pengujian Kandungan Emisi $\mathrm{O}_{2}$ dalam \% Vol

\begin{tabular}{|c|c|c|c|}
\hline \multirow{2}{*}{ RPM } & \multicolumn{3}{|c|}{ Hasil Pengujian Emisi $\mathrm{O}_{2}$ dalam \% } \\
\cline { 2 - 4 } & Polume \\
\hline Idle & 12,90 & $\begin{array}{c}\text { Premium }+ \\
\text { Biofuel 5\% }\end{array}$ & $\begin{array}{c}\text { Premium }+ \\
\text { Biofuel 20\% }\end{array}$ \\
\hline
\end{tabular}


Berdasarkan tabel di atas, maka data angka tersebut dapat digambarkan melalui grafik sebagai berikut:

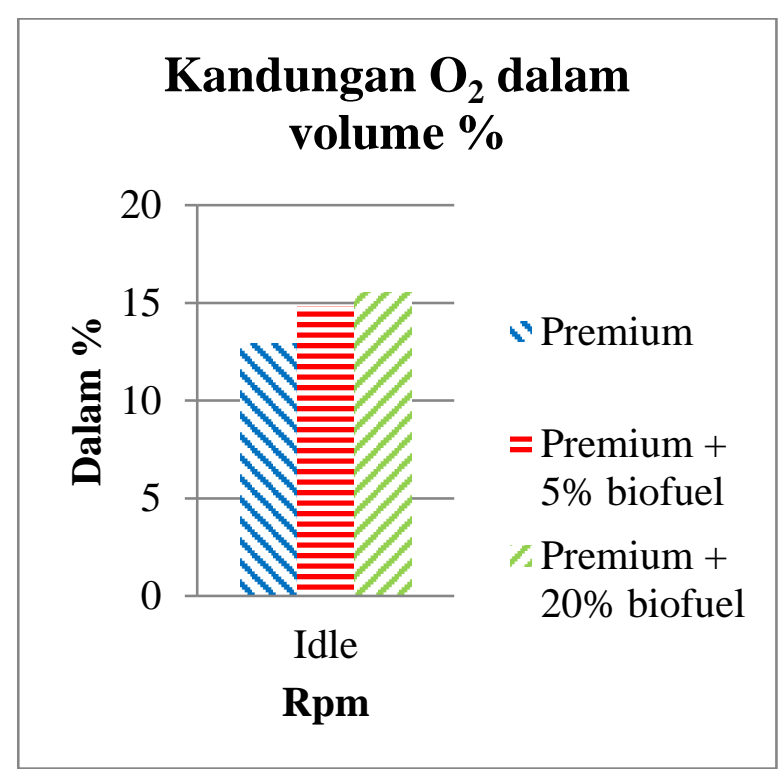

Gambar 6 Kandungan $\mathrm{O}_{2}$ dalam volume \%

Kosentrasi Oksigen menunjukkan jumlah udara yang masuk ke ruang bakar berbanding dengan jumlah bensin, angka ideal untuk oksigen pada emisi gas buang adalah berkisar antara $1 \%$ hingga $2 \%$.

Konsentrasi $\mathrm{O}_{2}$ yang tinggi menunjukan AFR yang terlalu kurus, kondisi ini dapat disebabkan oleh:

- AFR yang tidak tepat

- Kebocoran pada saluran intake

- Kegagalan pada sistem pengapian sehingga menyebabkan pembakaran tidak optimal

Kemudian jika kandungan $\mathrm{O}_{2}$ terlalu rendah kondisi ini menunjukkan bahwa AFR terlalu kaya.

Dari data diatas dapat diketahui bahwa kandungan $\mathrm{O}_{2}$ yang dihasilkan dari campuran premium dan biofuel $5 \%$ dan $20 \%$ lebih tinggi dibandingkan kandungan $\mathrm{O}_{2}$ pada premium murni, hal ini dimungkinkan karena titik nyala biofuel yang tinggi yaitu $46,50^{\circ} \mathrm{C}$ sedangkan titik nyala bensin -10 sampai $-15^{\circ} \mathrm{C}$ dan pada putaran rendah sudut pengapian cenderung mundur dan pembakaran menjadi terlambat sehingga oksigen dan bahan bakar tidak dapat terbakar sempurna sehingga ada sebagian $\mathrm{O}_{2}$ yang keluar pada saat proses pembuangan.

\section{KESIMPULAN}

1. Dari hasil percobaan yang telah dilakukan sebanyak 3 kali dapat diketahui bahwa reaktor pirolisis yang mempunyai kapasitas $1 \mathrm{~kg}$ dengan bahan baku botol plastik bekas (PET) dapat menghasilkan minyak dengan jumlah rata-rata sebanyak $250 \mathrm{ml}$.

2. Setelah dilakukan uji sampel pada minyak hasil pirolisis dengan bahan baku botol plastik (PET) hasilnya dimungkinkan mendekati bahan bakar bensin, karena pada saat di uji coba pada kendaraan mesin masih bisa menyala dengan normal tanpa ada masalah pada mesin.

3. Setelah dilakukan pencampuran antara bahan bakar premium dan biofuel hasil pirolisis dengan perbandingan premium 95\%: $5 \%$ biofuel, dan $80 \%$ : $20 \%$, kemudian dilakukan uji emisi pada sepeda motor hasilnya menunjukan bahwa kandungan $\mathrm{CO}$, $\mathrm{HC}, \mathrm{CO}_{2}$ dan $\mathrm{O}_{2}$ yang dimiliki masih aman digunakan karena masih berada dibawah ambang batas gas buang kendaraan bermotor.

\section{DAFTAR PUSTAKA}

[1] Budi, S U.,2013. Berbagai Metode Konversi Sampah Plastik Menjadi Bahan Bakar Minyak. Jurnal Teknik 3(1) 32-38.

[2] Ermawati, R., 2011. Konversi Limbah Plastik Menjadi Sumber Energi Alternatif. Jurnal Riset Industri $\mathrm{v}(3)$ : 257-263.

[3] Fauji, M., 2015. Pengaruh Bioetanol Terhadap Lambda Dan Emisi Gas Buang Pada Sepeda Motor Empat Tak Satu Silinder Berbahan Bakar Premium. Skripsi Fakultas Teknik Universitas Negeri Semarang.

[4] Santoso, J., 2010. Uji Sifat Pirolisis Dan Uji Performasi Kompor Berbahan Minyak Pirolisis Dari Sampah Plastik. Skipsi Fakultas Teknik Universitas Sebelas Maret Surakarta

[5] Zuhda, F., 2015. Pengaruh Campuran Minyak Limbah Plastik Dengan Premium Dan Pertamax Terhadap Emisi Gas Buang Sepeda Motor. Skripsi Fakultas Teknik Universitas Negeri Semarang 